\title{
What attributes of extra virgin olive oil are really important for consumers: a meta- analysis of consumers' stated preferences
}

\author{
Teresa Del Giudice ${ }^{1,2^{*}}$, Carla Cavallo ${ }^{1,2}$, Francesco Caracciolo ${ }^{1,2}$ and Gianni Cicia ${ }^{1,2}$
}

\footnotetext{
* Correspondence: agriqual@unina.it ${ }^{1}$ Department of Agricultural Sciences, University of Naples Federico II, Via Università 100, 80055, Portici $(\mathrm{Na})$, Italy ${ }^{2}$ MiPAAF - ex Centro per la Formazione in Economia e Politica dello Sviluppo Rurale, Via Università 96, 80055, Portici (Na), Italy
}

\begin{abstract}
The literature on food economics has extensively analyzed consumer preferences for extra-virgin olive oil attributes. In order to summarize and systematize the information gained in recent years, it seems appropriate to make a critique of the existing literature. First, we carry out a narrative systematic review of the literature on the topic. Subsequently, using only the empirical contributions which provide estimates of consumer willingness to pay for quality attributes including a measure of the goodness of the estimation (20 papers with 78 estimates), a meta-analysis was conducted to synthesize the empirical results obtained.

JEL classification: D12; C25; Q18

Keywords: Meta-analysis; Consumers preferences; Extra-virgin olive oil
\end{abstract}

\section{Background}

Extra-virgin olive oil (EVO) is an important element in the Mediterranean diet and a major agricultural crop for Southern European countries in terms of both farm income and cultivated area (De Graaff and Eppink 1999; Owen et al. 2000; Pupo D’Andrea, 2007; Marchini et al. 2010). Moreover, given the increased popularity of the Mediterranean diet among consumers in the US, Canada, Australia and large parts of Asia, EVO consumption has grown almost worldwide (Santosa and Guinard 2011; International Olive Oil Council 2012). Contextually, olive-oil production has switched from low yields and low-input cultivation to a capital-intensive farming system involving innovations in both agricultural practices and processing techniques. This has led to a considerable improvement in EVO nutritional characteristics accompanied by a profound change in sensory profile, turning a traditional food, with well known organoleptic features, into a brand new kind of dressing.

All the described processes have made it necessary for traders, researchers and policy makers to gain insights into consumer preferences for intrinsic and extrinsic characteristics of EVO, which have become increasingly complex and structured (Sillani et al. 2014). In recent years, this has led to a wide range of scientific contributions aiming to identify the chief EVO attributes for the postmodern consumer (Cicia et al. 2012). This research field has made extensive use of discrete choice methods based on random utility models, which help identify product characteristics most relevant to consumers,

(c) 2015 Del Giudice et al. This is an Open Access article distributed under the terms of the Creative Commons Attribution License (http://creativecommons.org/licenses/by/4.0), which permits unrestricted use, distribution, and reproduction in any medium, provided the original work is properly credited. 
also valuing the willingness to pay for a product with such characteristics. Since the surveys were carried out in different countries, with different sample sizes, different statistical designs and often considering different choice experiment attributes as well, the results emerging from the literature are somewhat heterogeneous, although there are some well defined trends.

In order to summarize and systematize the information gained in recent years on consumer preferences related to extra-virgin olive oil, it thus seems appropriate to offer a critique of the existing literature. Our analysis can be divided into two distinct but complementary parts. The first is dedicated to a narrative systematic review of the literature on the topic. Subsequently, using 20 empirical contributions which provide estimates of consumers' willingness to pay for quality attributes including a measure of the goodness of the estimation, a meta-analysis was conducted to synthesize the empirical results obtained.

In this paper we refer to the definitions of systematic review and meta-analysis provided by the Cochrane Collaboration (2009) and by the PRISMA Statement (Moher et al. 2009): "A systematic review is a review of a clearly formulated question that uses systematic and explicit methods to identify, select, and critically appraise relevant research, and to collect and analyze data from the studies that are included in the review. Statistical methods (meta-analysis) may or may not be used to analyze and summarize the results of the included studies. Meta-analysis refers to the use of statistical techniques in a systematic review to integrate the results of included studies". In as much as is allowed by the subject of our analysis, in our study we followed the instructions provided by the PRISMA Statement (Moher et al. 2009) in order to carry out an appropriate review. The paper is organized as follows. In second section the narrative systematic review is described, summarizing the main results of the literature dealing with EVO attributes. The statistical model used in the meta-analysis and the empirical results are discussed in third section. Fourth section comprises the discussion, study limitations and some concluding remarks.

\section{Narrative systematic review}

The Narrative Systematic Review was carried out to summarize the literature about consumer preferences relating to EVO characteristics. The chosen period covered the years between 1994, when the first work, to our knowledge, about the subject emerged, and June 2014. The research was carried out using the main scientific/economic research databases: 1. Thomson Reuters (ISI) Web of Knowledge 2. SciVerse Scopus, 3. EconLit 4. Wiley Online Library 5. Emerald Insight 6. Google Scholar 7. AgEcon Search, 8. CiteSeerX $\beta$ 9. Microsoft Academic Search; 10. Google, Bing, Abacho, etc.

The survey identified around 78 major works which studied consumer preferences for EVO features. The scientific production related to this line of research has not appeared to decline at all. As for the countries investigated, about $73 \%$ of the contributions focus on Mediterranean countries, which are traditionally major producers and consumers of olive oil, with Italy being the most commonly analyzed, accounting for $40 \%$ of all contributions. The remaining $27 \%$ of works are distributed between Northern European countries (17 \%) and the rest of the world (10\%).

As regards publication type, $70 \%$ of the articles analyzed were published in peer-reviewed journals, $20 \%$ of contributions were presented at international conferences, and $10 \%$ are 
termed final research reports. Regarding the specific contents of the various works, we can categorize the large number of articles according to two different elements. The first relates to investigation methodology, while the second concerns research questions to be solved.

Methodological approaches followed by the selected works to analyze consumer preferences show a large share of discrete choice models, applied with many variations. In particular, Conjoint Analysis and Random Utility Models (RUM) are the most widely used. As regards Conjoint Analysis, several studies have used this approach to assess the relative importance to consumers of different attributes and to define a hypothetical most preferred product (Cicia and Perla 2000; Van der Lans et al. 2001, Martínez et al. 2002; Soler et al. 2002; Krystallis and Ness 2005; Bracco et al. 2009; Jiménez-Guerrero et al. 2012; Mtimet et al. 2008, 2011, 2013; Di Vita et al. 2013; Sillani et al. 2014).

By contrast, widely adopted Random Utility Models (RUM) provide the impact of product attributes on choices and estimation of the willingness to pay (WTP) (Cicia et al. 2002; Ward et al. 2003; Scarpa and Del Giudice 2004; Cicia et al. 2005; Dekhili and d'Hauteville 2009; Finardi et al. 2009; Finardi 2010; Chan-Halbrendt et al. 2010; Menapace et al. 2011; Aprile et al. 2012; Delgado et al. 2013; Mtimet et al. 2013; Vlontzos and Duquenne 2014; Yangui et al. 2013, 2014a, 2014b).

For instance, Cicia et al. (2005) valued at one euro per bottle the attribute of Italian product origin (COOL attribute) ascribed by Italian consumers. Amongst the methodologies for analyzing consumer preferences, some studies asked interviewees to rank attributes according to their perceived importance (Del Giudice and D'Elia 2001).

Other empirical approaches adopt the hedonic price method (Karipidis et al. 2005; Ribeiro and Santos 2005; Carlucci et al. 2014) or multi-criteria analysis (Sandalidou et al. 2002; Bevilacqua et al. 2012), while others follow mainly qualitative approaches, such as means-end chains, laddering interviews or focus groups. Some interdisciplinary studies comprise features of econometric analysis and sensory analysis (McEwan 1994; Morales et al. 1997; Monteleone et al. 1997; Pagliarini et al. 1994; Caporale et al. 2004, 2006; Delgado and Guinard 2011, 2012; Finotti et al. 2007, Favati et al. 2013, Fregapane et al. 2013, Nakano et al. 2013). Finally, other modeling and theoretical frameworks comprise both qualitative analysis techniques such as laddering (Nielsen et al. 1998) and supply chain and sector analysis (Baourakis and Apostolakis 1999; Belletti and Marescotti 1998; Fucito and Vizzarri 2004; Mili and Zúñiga 2001; Mili 2006; Del Giudice et al. 2012).

As regards the aims of the selected papers, most investigated consumer preferences for specific extra-virgin olive oil attributes: they analyzed intrinsic (taste, appearance, color) and extrinsic (packaging, certifications, label, brand, etc.) product attributes. Thus, in the sections below, we highlight the main conclusions made by the literature sorted by the most commonly investigated attributes.

\section{Olive geographical origin certification}

Early studies on this topic indicated geographical origin of the olives as the main focus (McEwan 1994; Monteleone et al. 1997; Bech-Larsen et al. 1996; Belletti and Marescotti 1998; Nielsen et al. 1998; Tsakiridou et al. 2006). Geographical origin has received ever-increasing attention over the years. It has been extensively shown that, when making purchasing decisions, consumers, albeit from different geographical and socio-economic realities, attach a priority value to information about the country of origin of the olives concerned (Nielsen et al. 1998; Van der Lans et al. 2001; Fotopoulos and Krystallis 2002; Krystallis and Ness 2005; 
Ward et al. 2003; Scarpa et al. 2005; Gázquez-Abad and Sánchez-Pérez 2009; Del Giudice and D’Elia 2001, Dekhili et al. 2011; Aprile et al. 2012; Piccolo et al. 2013).

The Geographical Origin attribute was also analyzed through the study of influences exerted by Community certification of origin (PDO and PGI, EC Regulation 509/06 and 510/06) on individual preferences. Several studies agree on two common conclusions (Van der Lans et al. 2001; Scarpa and Del Giudice 2004; Menapace et al. 2008; Bracco et al. 2009; Fucito and Vizzarri 2004; Finco et al. 2010).

The first conclusion concerns the considerable importance of olive origin as a key element in individual choices. In many markets, origin indication is synonymous with a local product. Consumers seem to prefer, regardless of other items, the typical product of the area of consumption. Since the sensory characteristics of olive oil and extravirgin olive oil are greatly affected by cultivars and agronomic techniques, knowledge of origin gives the consumer assurances concerning product taste characteristics.

The second conclusion is that EC designations of origin (PDO and PGI) have never fully expressed their potential as differentiation and protection tools. Indeed, they are still little known to consumers, who continue to use other quality signals and origin certification, such as trademarks evocative of particular production areas, trademarks traditionally associated with specific origins, certification of private standards focused on olives origin or label information about bottling location, which often, before the recent legislation came into force (EU Reg. 182/09 and EU Reg. 1169/2011), was unrelated to the source of olives.

\section{Product food safety}

A second group of attributes, which has received wide attention from papers discussing EVO health aspects, consists in food safety and traceability. This line of research also includes attention toward organic certification. This attribute has a twofold value for the consumer: first it indicates attention toward health and preservation of the natural environment (Cicia et al. 2009). Organic certification has been shown to be positively perceived by consumers, although more than twenty years after EU regulation on organic produce and its definition came into force, consumer information levels were still unsatisfactory (Van der Lans et al. 2001; Soler et al. 2002; Fotopoulos and Krystallis 2002; Cicia et al. 2002; Zanoli et al. 2002; Sandalidou et al. 2002; Del Giudice et al. 2012).

In more recent works, the relation between origin and traceability emerges quite strongly (Leonetti et al., 2009; Chan-Halbrendt et al. 2010; Mane-Kapaj et al. 2010; Gázquez-Abad and Sánchez-Pérez 2009; Cicia et al. 2005; Menapace et al. 2008; Deselnicu et al. 2013; Gambaro et al. 2013). Traceability and related labeling information have become increasingly analyzed elements. Traceability means the ability to track food through all stages of production, processing and distribution. Traceability was introduced by the EU's General Food Law (EC Reg. 178/2002). It has been generally shown that information on traceability influences consumer choices, which are ever more geared to food safety (Soler et al. 2002; Krystallis and Ness, 2005). However, the studies in question indicate that consumers consider information about the origin of the olives the most important element for traceability of the product. Knowledge of all stages of production, processing and distribution does not seem to affect consumer choice, the information about the origin of the raw material seems more important (Cicia et al. 2005; Di Vita et al. 2013). 


\section{Brand}

Another relevant attribute within consumer preferences is represented by brand (Baourakis and Baltas 2003; Bower et al. 2003; Del Giudice and D'Elia 2001; Cicia et al. 2005; Bracco et al. 2009; Dekhili and d'Hauteville 2009; Gázquez-Abad and SánchezPérez 2009; Jiménez-Guerrero et al. 2012). In particular, the literature highlights the preference of consumers for traditionally known brands and private labels, both with an increasing information value and reassuring features for the consumer.

Price

Price clearly emerges as a "particular" attribute as stated by the literature, with regard to the influence upon purchase choices and on perception of extra-virgin olive oil quality. Indeed, several studies have shown the considerable attention paid to price on the part of consumers (McEwan 1994; Baourakis and Apostolakis, 1999; Baourakis and Baltas 2003; Lazaridis 2004; Gázquez-Abad and Sánchez-Pérez 2009, Carlucci et al. 2014). Other studies (Cicia et al. 2002; Martínez et al. 2002; Scarpa and Del Giudice 2004) highlight the role played by the price factor as a quality indicator for extra-virgin olive oil. Indeed, very often the preference toward this attribute seems to follow a triangular path typical of quality products (Cicia and Perla 2000).

\section{Sensory attributes}

The last group of attributes analyzed comprises all product sensory and taste aspects. This kind of analysis showed significant changes over the period. In general, in the past, olive oil taste and color were considered two of the attributes that most influenced consumer perception and purchase choice, without, however, identifying them individually as being present (McEwan 1994; Finotti et al. 2007; Monteleone et al. 1997; Cicia et al. 2002).

Further developments in the way EVO sensory and taste aspects are described and researched both at production and processing level have led to in-depth analysis of consumer preferences. On the production side there has been a trend toward oils which, thanks to innovations in production techniques introduced over the past two decades, result in a product with enhanced sensory characteristics (pungent, bitter, fruity, etc.). On the consumption side, because of the strong link with traditional preferences and thanks to the educational role played by branded products and GDO private labels toward tasting, there is now a generation of EVO users who seem to prefer a product with a quite plain, neutral taste, generating a serious split in the market (Leonetti et al. 2009; Santosa et al. 2010; Mtimet et al. 2008, 2011, 2013; Caporale et al. 2006; Delgado and Guinard 2011, 2012; Delgado et al. 2013; Recchia et al. 2012; Bevilacqua et al. 2012; Del Giudice et al. 2012).

\section{Econometric meta-analysis}

Meta-analysis is increasingly proving that it could play a valuable role in objectively and effectively exploring topics which are extensively debated in the scientific literature. Meta-analysis as a tool for scientific investigation was first used in the early 20th century (Simpson and Pearson 1904), although the term itself was first coined only in 1976 (Glass 1976).

This approach has also benefited in recent years from the process that has led to massive web indexing and sharing of the results of scientific research. Although its 
main application is in the medical sciences, studies focusing on meta-analysis are becoming more widespread and accepted in other disciplines, including economics and social sciences (Nelson and Kennedy 2009).

It is undeniable that having a comprehensive and objective view of what research has produced on the subject of interest over the years represents the first stage for any researcher interested in providing a new contribution to knowledge, taking advantage of the spillover offered by previous scientific production ${ }^{\mathrm{a}}$. With regard to the analysis of consumer EVO preferences, both quality and quantity of scientific output allow the main results to be synthesized and systematized. Within this scope, a meta-analysis study, thanks to the characteristics of the regression models in terms of inference on reality, seems an efficient choice. Therefore, the aim of the meta-analysis proposed herein is to provide a statistically rigorous synopsis of the findings in the literature on consumer preferences for extra virgin olive oil attributes.

Our approach analyzes the WTP of consumers for several EVO attributes. As previously stated, many studies on this subject adopt the discrete choice method based on random utility theory ${ }^{\mathrm{b}}$. If the price is included among the attributes, it is thus possible to obtain the preference for the various attributes considered, measured in monetary terms, as WTP. However, direct comparison among studies of WTPs for the various attributes is not strictly feasible in these terms as the results of each estimation are in local currency and they refer to specific space-time situations.

In light of the above considerations, the variable of interest, or the dependent variable of our model, WTP, was transformed into the relative change with respect to the base price of EVO as reported in each specific study. Meta-analysis may thus summarize the general indications on willingness to pay for different attributes by using results from studies from different sites, surveys, methodologies, and sample characteristics.

From an empirical point of view, not all the analyzed studies provided information directly usable for our purpose: only 20 studies explicitly provided the estimated WTP including a measure of the variance of the estimation, information necessary for implementation of random or fixed-effect models. Since each study usually considers jointly the preferences for different attributes, thus providing several estimates of WTP, our meta-analysis collected 78 WTPs overall from 20 studies written during the decade 2004-2014 (see Table 3). In order to avoid publication bias, also "non peer-reviewed articles" were included in the metaanalysis (Duval and Tweedie 2000; Rothstein et al. 2006). The explanatory variables used in the meta-analysis are shown in Table 1 with some descriptive statistics.

Table 1 Explanatory variables used in the meta-analysis

\begin{tabular}{lccc}
\hline Variable & Mean value & Min & Max \\
\hline WTP (relative variation) & 0.46 & -0.92 & 0.98 \\
Olive Origin certification & 0.30 & 0 & 1 \\
Brand & 0.10 & 0 & 1 \\
Neutral taste & 0.15 & 0 & 1 \\
Traceability & 0.07 & 0 & 1 \\
Organic Certification & 0.12 & 0 & 1 \\
Peer-reviewed article & 0.60 & 0 & 1 \\
Italy-based survey & 0.30 & 0 & 1 \\
\hline
\end{tabular}


There are three parametric methods most widely used within meta-analysis: 1. Linear regression analysis model (or meta-regression); 2. Fixed-effect meta-regression analysis; 3. Random-effect meta-regression analysis.

The Linear regression analysis model (or meta-regression) follows the ordinary least squares approach. Specifically, we assume that each $i$-study of $n$ total studies provided an estimate of the relative willingness to pay equal to $W_{T P}$ :

$$
W T P_{i}=\mathbf{x}_{i} \boldsymbol{\beta}+u_{i}, \text { with } u_{i} \sim N\left(0, \sigma^{2}\right)
$$

where $\mathbf{x}_{i}$ is a $1 \times k$ vector of covariates (including intercept) that characterizes the study $i$ and $\boldsymbol{\beta}$ is a $k \times 1$ coefficient vector. Standard error estimates are provided through a bootstrap procedure to prevent possible estimation bias due to heteroskedasticity.

Meta-regression assumes that all the estimates of WTP included in the meta-analysis have the same precision or variability. When the confidence interval or the variance of WTP is available, it may be taken into account by adopting a variance weighted OLS. The literature on meta-analysis refers to this specification as Fixed-effect meta-regression analysis. In this case Eq. 1 becomes:

$$
W T P_{i}=\mathbf{x}_{i} \boldsymbol{\beta}+e_{i}, \text { with } e_{i} \sim N\left(0, \sigma_{\mathrm{i}}^{2}\right)
$$

Equation 2 can be estimated by weighted least squares, with the weights $1 / \sigma_{\mathrm{i}}^{2}$ where $\sigma_{\mathrm{i}}^{2}$ is the estimated variance of the parameter provided by the $i$-th study.

However, by construction, fixed effect meta-regression analysis assumes that betweenstudy variability of the estimates are equal to zero. In order to overcome this limitation random effect meta-regression analysis estimates a new parameter $\left(\mathrm{\tau}^{2}\right)$ for taking between-study variability into account:

$$
W T P_{i}=\mathbf{x}_{i} \boldsymbol{\beta}+e_{i}+u_{i}, \text { with } u_{i} \sim N\left(0, \mathrm{\tau}^{2}\right) \text { and } e_{i} \sim N\left(0, \sigma^{2}{ }_{\mathrm{i}}\right)
$$

The estimation procedure of Eq. (3) consists of a first estimate of $\tau^{2}$ (variance between studies) and then in an estimate of the coefficients $\beta$ through the least squares method weighted by using $1 /\left(\sigma_{i}^{2}+\tau^{2}\right)$ as weights. The algorithm is iterative and follows the procedure suggested by Thompson and Sharp (1999).

In particular, having set an initial value for $\tau^{2}$, the estimate of $\tau^{2}$ is based on the following log-likelihood function maximization:

$$
\mathrm{L}_{\mathrm{R}}\left(\tau^{2}\right)=-\frac{1}{2} \sum_{i}\left\{\log \left(\sigma_{i}^{2}+\tau^{2}\right)+\frac{\left(y_{i}-\mathbf{x}_{i} \hat{\boldsymbol{\beta}}\right)^{2}}{\sigma_{i}^{2}+\tau^{2}}\right\}-\frac{1}{2} \log \left|\mathbf{X}^{\prime} \mathbf{V}^{-1} \mathbf{X}\right|
$$

where $\mathbf{V}=\operatorname{diag}\left(\sigma_{1}^{2}+\tau^{2}, \sigma_{2}^{2}+\tau^{2}, \ldots, \sigma_{n}^{2}+\tau^{2}\right)$ and $\hat{\boldsymbol{\beta}}=\left(\mathbf{X}^{\prime} \mathbf{V}^{-1} \mathbf{X}\right)^{-1} \mathbf{X}^{\prime} \mathbf{V}^{-\mathbf{1}} \mathbf{y} \quad$ (Harville 1977).

From the sum of the squares of the weighted errors, $Q_{E}=\sum_{i}\left(\frac{y_{i}-\mathbf{x}_{i} \hat{\boldsymbol{\beta}}}{\sigma_{i}}\right)^{2}$ (Lipsey and Wilson 2001) it is possible to calculate the measure of the percentage of the residual variation that is attributable to between-study heterogeneity: 


$$
I^{2}=\max \left\{\frac{Q_{E}-(n-k)}{Q_{E}}, 0\right\} .
$$

The last two models are particularly useful when the purpose of studies is to estimate the "size effect" (effectiveness of a medicinal product, willingness to pay for a food attribute, etc.), exploiting the information from the confidence intervals of the measure.

In this specific study we apply all three models. For the estimation of the last two models we also use a measure of the variance of the WTP as estimated in the individual studies, in order to weight the effect size of each case study with an index of the goodness of the estimate.

Table 2 reports the results of the three estimates. All the exogenous variables considered show the same direction in the three different specifications. Of the three specifications, the fixed-effect meta-regression model seems to perform best, showing overall a higher significance level of the coefficients. This result is formally confirmed by the Cochran $\left(\mathrm{Q}_{\mathrm{E}}\right)$ test and by the Higgins heterogeneity measure $\left(\mathrm{I}^{2}\right)$ (Higgins and Green 2008). This specific result supports the outcomes of the "fixed effects model", implying the existence of a "true effect size" similar for all the studies, and the WTP differences reported in several studies are not statistically significant. In other words, the variation in the WTP for the attributes would appear the same for all studies, albeit conducted in different countries and at different times.

This result might arise from the specific design of the dependent variable as a percentage change with respect to a base price. By using this procedure the differences between the estimates based on study-specific characteristics might be minimized.

The results of our meta-analysis indicate that known brand, organic certification, olive origin certification (including European PDO, PGI and private certifications of country of origin) and neutral taste have a positive influence on consumers' WTP. The

Table 2 Assessment of implemented econometric models

\begin{tabular}{|c|c|c|c|c|c|c|}
\hline \multirow[t]{2}{*}{ Variable } & \multicolumn{2}{|c|}{ Meta-regression } & \multicolumn{2}{|c|}{ Fixed effect meta-regression } & \multicolumn{2}{|c|}{ Random effect meta-regression } \\
\hline & Coeff & std-dev & Coeff & std-dev & Coeff & std-dev \\
\hline $\begin{array}{l}\text { Olive origin } \\
\text { certification }\end{array}$ & $0.474^{* * *}$ & 0.144 & $0.489^{* * *}$ & 0.151 & $0.496^{* * *}$ & 0.107 \\
\hline Brand & $0.521^{* *}$ & 0.243 & $0.608^{* * *}$ & 0.207 & $0.531^{* * *}$ & 0.193 \\
\hline Neutral taste & 0.251 & 0.173 & $0.197^{* * *}$ & 0.056 & 0.194 & 0.21 \\
\hline Traceability & 0.033 & 0.041 & 0.145 & 0.105 & 0.12 & 0.08 \\
\hline Organic certification & $0.393^{*}$ & 0.215 & $0.577^{* * *}$ & 0.139 & 0.403 & 0.32 \\
\hline Peer-reviewed article & -0.276 & 0.192 & $-0.355^{* * *}$ & 0.124 & $-0.324^{* * *}$ & 0.096 \\
\hline Italy-based survey & $-0.416^{* * *}$ & 0.112 & $-0.646^{* * *}$ & 0.238 & $-0.459^{* * *}$ & 0.143 \\
\hline Constant & 0.579 & 0.439 & 0.12 & 0.215 & 0.245 & 0.201 \\
\hline$R^{2}$ & 0.3078 & & 0.3192 & & & \\
\hline$T^{2}$ & & & & & 0.029 & \\
\hline$P^{2}$ & & & & & $15.20 \%$ & \\
\hline Adj $R^{2}$ & & & & & $81.28 \%$ & \\
\hline $\mathrm{Q}_{\mathrm{E}}$ & & & & & $\begin{array}{l}64.37\left(x^{2} 89.39 ; \text { df 69; }\right. \\
p<0.05)\end{array}$ & \\
\hline$F(8,69)$ & 3.84 & & 4.05 & & 8.05 & \\
\hline Prob $>F$ & 0.0009 & & 0.0005 & & $<0.0001$ & \\
\hline
\end{tabular}

\#obs: 78 || ${ }^{*} p<0.1 ;{ }^{* *} p<0.05 ;{ }^{* * *} p<0.01$. 
Table $\mathbf{3}$ List of studies included in the meta-regression analysis

\begin{tabular}{|c|c|c|c|c|c|}
\hline Authors & Year & Title & Source title & $\begin{array}{l}\text { Publication type (report, } \\
\text { peer-reviewed article, etc.) }\end{array}$ & $\begin{array}{l}\text { Study } \\
\text { area }\end{array}$ \\
\hline G. Cicia e C. Perla & 2000 & $\begin{array}{l}\text { La percezione della qualità nei consumatori di prodotti biologici: } \\
\text { uno studio sull'olio extra-vergine di oliva tramite conjoint analisys }\end{array}$ & $\begin{array}{l}\text { Qualità e valorizzazione nel mercato } \\
\text { dei prodotti agroalimentari tipici }\end{array}$ & Book chapter & Italy \\
\hline $\begin{array}{l}\text { I. van der Lans, K. van Ittersum, } \\
\text { A. De Cicco, M. Loseby }\end{array}$ & 2001 & $\begin{array}{l}\text { The role of the region of origin and EU certificates of origin } \\
\text { in consumer evaluation of food products }\end{array}$ & $\begin{array}{l}\text { European Review of Agricultural } \\
\text { Economics }\end{array}$ & Peer-reviewed article & Italy \\
\hline G. Cicia, T. Del Giudice, R. Scarpa & 2002 & $\begin{array}{l}\text { Consumers' perception of quality in organic food A random } \\
\text { utility model under preference heterogeneity and choice } \\
\text { correlation from rank-orderings }\end{array}$ & British Food Journal & Peer-reviewed article & Italy \\
\hline R. W. Ward, J. Briz, I. de Felipe & 2003 & $\begin{array}{l}\text { Competing Supplies of Olive Oil in the German Market: } \\
\text { An Application of Multinomial Logit Models }\end{array}$ & Agribusiness & Peer-reviewed article & Germany \\
\hline R. Scarpa, T. Del Giudice & 2004 & $\begin{array}{l}\text { Market Segmentation via Mixed Logit: Extra-Virgin Olive } \\
\text { Oil in Urban Italy }\end{array}$ & $\begin{array}{l}\text { Journal of Agricultural \& Food } \\
\text { Industrial Organization }\end{array}$ & Peer-reviewed article & Italy \\
\hline G. Cicia, T. Del Giudice, R. Scarpa & 2005 & $\begin{array}{l}\text { Welfare Loss due to Lack of Traceability in Extra-virgin } \\
\text { Olive Oil: a Case Study }\end{array}$ & Cahiers Options Méditerranéennes & Peer-reviewed article & Italy \\
\hline S. Dekhili, F. D'Hauteville & 2009 & $\begin{array}{l}\text { Effect of the region of origin on the perceived quality } \\
\text { of olive oil: An experimental approach using a control group }\end{array}$ & Food Quality and Preference & Peer-reviewed article & $\begin{array}{l}\text { Tunisia- } \\
\text { France }\end{array}$ \\
\hline $\begin{array}{l}\text { C. Finardi, C. Giacomini, D. } \\
\text { Menozzi, C. Mora }\end{array}$ & 2009 & $\begin{array}{l}\text { Consumer preferences for country-of-origin and health } \\
\text { claim labelling of extra-virgin olive-oil }\end{array}$ & $\begin{array}{l}\text { 113th EAAE Seminar "A resilient } \\
\text { European food industry and food } \\
\text { chain in a challenging world" }\end{array}$ & Conference paper & Italy \\
\hline $\begin{array}{l}\text { C. Chan-Halbrendt E. Zhllima, } \\
\text { G. Sisior, D. Imami, L. Leonetti }\end{array}$ & 2010 & Consumer Preferences for Olive Oil in Tirana, Albania & $\begin{array}{l}\text { International Food and Agribusiness } \\
\text { Management Review }\end{array}$ & Peer-reviewed article & Albania \\
\hline C. Finardi & 2010 & $\begin{array}{l}\text { Preferenze dei consumatori per attributi di qualità } \\
\text { dell'olio extravergine di oliva. Una indagine empirica }\end{array}$ & AgriRegioniEuropa & Peer-reviewed article & Italy \\
\hline $\begin{array}{l}\text { L. Menapace, G. Colson, C. } \\
\text { Grebitus, M. Facendola }\end{array}$ & 2011 & $\begin{array}{l}\text { Consumers' preferences for geographical origin labels: } \\
\text { evidence from the Canadian olive oil market }\end{array}$ & $\begin{array}{l}\text { European Review of Agricultural } \\
\text { Economics }\end{array}$ & Peer-reviewed article & Canada \\
\hline $\begin{array}{l}\text { N. Mtimet, K. Ujiie, K. Kashiwaghi, L. } \\
\text { Zaibet, M. Nagaki }\end{array}$ & 2011 & $\begin{array}{l}\text { The effects of Information and Country of Origin } \\
\text { on Japanese Olive Oil Consumer Selection }\end{array}$ & $\begin{array}{l}\text { EAAE } 2011 \text { Congress "Change } \\
\text { and Uncertainty Challenges for } \\
\text { Agriculture, Food and Natural Resources" }\end{array}$ & Conference paper & Japan \\
\hline M.C. Aprile, V. Caputo, R.M. Jr. Nayga & 2012 & & $\begin{array}{l}\text { International journal of consumer } \\
\text { studies }\end{array}$ & Peer-reviewed article & Italy \\
\hline
\end{tabular}


Table 3 List of studies included in the meta-regression analysis (Continued)

\begin{tabular}{|c|c|c|c|c|c|}
\hline & & $\begin{array}{l}\text { Consumers' valuation of food quality labels: the case } \\
\text { of the European geographic indication and organic } \\
\text { farming labels }\end{array}$ & & & \\
\hline $\begin{array}{l}\text { C. Delgado, A. Gomez-Rico, } \\
\text { J.X. Guinard }\end{array}$ & 2013 & $\begin{array}{l}\text { Evaluating bottles and labels versus tasting the oils blind: } \\
\text { Effects of packaging and labeling on consumer preferences, } \\
\text { purchase intentions and expectations for extra virgin olive oil }\end{array}$ & Food Research International & Peer-reviewed article & $\begin{array}{l}\text { USA/ } \\
\text { California }\end{array}$ \\
\hline $\begin{array}{l}\text { G. Di Vita, M. D’Amico, } \\
\text { G. La Via, E. Caniglia }\end{array}$ & 2013 & $\begin{array}{l}\text { Quality Perception of PDO extra-virgin Olive Oil: Which } \\
\text { attributes most influence. Italian consumers? }\end{array}$ & Agricultural Economics Review & Peer-reviewed article & Italy \\
\hline A. Yangui, M. Costa-Font, J.M. Gil & 2013 & $\begin{array}{l}\text { The effect of food related personality traits and lifestyle } \\
\text { orientation on consumer's behavior related to extra } \\
\text { virgin olive oil: estimation of an extended hybrid choice model }\end{array}$ & 4th ICAAAE & Conference Paper & Spain \\
\hline $\begin{array}{l}\text { N. Mtimet, L. Zaibet, C. Zairi, } \\
\text { H. Hzami }\end{array}$ & 2013 & $\begin{array}{l}\text { Marketing Olive Oil Products in the Tunisian Local Market: } \\
\text { The Importance of Quality Attributes and Consumers' Behavior }\end{array}$ & $\begin{array}{l}\text { Journal of International Food \& } \\
\text { Agribusiness Marketing }\end{array}$ & Peer-reviewed article & Tunisia \\
\hline G. Vlontzos, M.N. Duquenne & 2014 & $\begin{array}{l}\text { Assess the impact of subjective norms of consumers' } \\
\text { behaviour in the Greek olive oil market }\end{array}$ & $\begin{array}{l}\text { Journal of Retailing and Consumer } \\
\text { Services }\end{array}$ & Peer-reviewed article & Greece \\
\hline A. Yangui, M. Costa-Font, J.M. Gil & 2014 & $\begin{array}{l}\text { Revealing additional preference heterogeneity with an } \\
\text { extended random parameter logit model: the case of } \\
\text { extra virgin olive oil }\end{array}$ & $\begin{array}{l}\text { Spanish Journal of Agricultural } \\
\text { Research }\end{array}$ & Peer-reviewed article & Spain \\
\hline $\begin{array}{l}\text { A. Yangui, F. Akaichi, M. Costa-Font, } \\
\text { J.M. Gil }\end{array}$ & 2014 & $\begin{array}{l}\text { Are ranking preferences information methods comparable } \\
\text { with the choice experiment information in predicting actual behavior? }\end{array}$ & EAAE 2014 Congress & Conference Paper & Spain \\
\hline
\end{tabular}


opposite consideration can be made for articles published in peer-reviewed journals, and those referring to Italian consumers. Thus Italian consumers show overall less importance to quality attributes compared to consumers from other countries ${ }^{\mathrm{c}}$, while articles not published in peer-reviewed journals seem to overestimate the real WTP for the attributes. A possible explanation could be related to the difficulty being published in a peer review journal since higher WTP estimates are considered less reliable. Finally, traceability does not seem to influence WTP. This result is related to the greater influence that information on the area of origin has on consumer choices. Information on the origin of the olives seems the most important aspect of traceability for EVO consumers. Coefficients measure the relative variation of the final price of EVO in terms of WTP, and therefore can be interpreted also as measure of importance for the consumers of the attributes. This means that brand, organic certification and origin certification can be considered the product attributes showing the greatest influence on consumer willingness to pay. Finally, the neutral taste attribute shows the lowest WTP.

\section{Conclusions}

Analysis of the literature on EVO consumer preferences and the meta-analysis implemented on the information attained allow some interesting considerations to be made. The first concerns the importance of the research strand which continues to interest not only traditional producer and consumer countries but also new geographical areas, such as China and Japan, which have only recently discovered the product's nutritional and gustatory value. The second concerns the evolution of factors/characteristics which have, over the years, been the subject of the literature. Constant value across the period in question is to be attributed to origin certification, in all its various specifications (PDO, PGI, and private certifications of country of origin) and, to a lesser extent, to the known brand. Such attributes represented the cardinal points of our analysis. In all the studies, as also shown by meta-analysis, origin and brand decidedly affect consumer preferences. In particular, all the studies carried out have shown unequivocally the strategic role played by knowledge, on the part of the end purchaser, of the oil's origin. This situation appeared so evident that the European Union issued EC Regulation 182/09 in 2009 with the aim of making information on product origin clear and mandatory on the label. This new regulatory scenario combined with what was already written on the known origin of the extra-virgin olive oil excludes this characteristic from the possible focuses of further innovative research. Investigating how product origin may affect purchases of extra-virgin oil becomes a question of valid research especially if the study is carried out in countries such as China, India or other economies considered potential wealthy markets for the product in question.

Brand is another important attribute: in recent years the role of private labels has acquired major strategic value. Indeed, national and international brands of the large retailers, thanks to the reputation that they have built up, manage to supply the consumer with a guarantee not only of organoleptic quality and food safety but also of environmental (integrated production with the use of low input) and social sustainability (ethical certifications like SA8000). Organic certification represents an element of product differentiation, related to safety and the environment, which the consumer clearly appreciates.

The third reflection concerns aspects of taste in the literature. Indeed, while in older contributions intrinsic attributes were explored without particular focus on the various 
specifications which they might assume, recent analyses have begun to define the various dimensions of the sensory profile of EVOs. This evolution is due to developments which have occurred in the sensory analysis of olive oil and in the use of panel tests as a monitoring tool and guide in quality oil production. To date, agronomic and sensory research has managed not only to identify what aspects of taste and smell are indicators of oil quality but also how the latter correlate with production techniques The situation which currently emerges is that a quality EVO has a sensory profile which is quite marked and well differentiated. By contrast, on the consumption side, the consumer prefers standard oils with little or no personality. This is amply highlighted by the results of the econometric model where neutral taste is ranked fourth in importance, after brand, organic certification and origin certification. This probably represents the question of the most topical interest. This aspect deserves a central position in future research since consumption preferences as described undermine all efforts to improve product quality made on the production side. Indeed, at present on the EVO market there is a serious discrepancy: producers who invested heavily in the past in improving product quality have had to overhaul their traditional production techniques, rewarded by the "experts" and "punished" by the market.

Finally, mention should be made of the limitations to the analysis. The first concerns the large number of studies, included in the econometric model, implemented in the countries where EVO is traditionally consumed. By contrast, consumer preferences for EVO in new markets, such as Asia, the US and Japan, have so far undergone little analysis.

The second is related to the number of papers included in the econometric analysis. Moreover, the sample size, although adequate for the objectives and the econometric approach of the analysis, did not allow the introduction of additional attributes in the econometric model considered.

A possible development of the analysis may involve the inclusion of papers belonging to a longer time period. This would allow the implementation of analytical models that can provide information on the evolution and changes in consumer preferences.

\section{Endnotes}

a"If I have seen far, it is by standing on the shoulders of giants" (Isaac Newton, 1676).

${ }^{b}$ An anonymous referee suggested including in the analysis estimates of "implicit prices" provided by hedonic price modeling as done by Deselnicu et al. (2013). Following the arguments provided by Brander and Koetse (2011) we included in our analyses only WTPs provided by stated preference techniques. This decision is also supported by the scarcity of available estimates using hedonic pricing (Carlucci et al. 2014).

${ }^{\mathrm{c}}$ One possible interpretation on the less importance to quality attributes given by Italian consumers could be associated to the fact that being Italy a producer country the oil olive price is on average lower than other non producing countries, and therefore also the WTP for the single attribute. However as highlighted by an anonymous referee, the same is not observed in other producer countries. Further investigations would be necessary on this specific point.

Competing interests

The authors declare that they have no competing interests.

Authors' contributions

TDG, CC, FC and GC are equally responsible of every paragraph of the paper. All authors read and approved the final manuscript. 


\section{Acknowledgements}

Research funded by the Italian Ministry of Agriculture (MiPAAF). Project: "Modelli statistici innovativi per la misura della Customer Satisfaction dei prodotti agro-alimentari: il caso dell'olio extra-vergine di oliva".

Received: 26 March 2014 Accepted: 6 May 2015

\section{Published online: 24 July 2015}

\section{References}

Aprile MC, Caputo V, Nayga RM Jr (2012) Consumers' valuation of food quality labels: the case of the European geographic indication and organic farming labels. Int J Consum Stud 36(2):158-165

Baourakis G, Apostolakis I (1999) A statistical assessment of consumers' criteria regarding organic agricultural products: the case of organic olive oil. Foundations Comput Decis Sci 24:21-31

Baourakis G, Baltas G (2003) Comparative behavioural analysis in selected EU countries: a brand modelling approach. Oper Res 3(2):165-182

Bech-Larsen T, Nielsen NA, Grunert KG (1996) Means-End Chains for low involvement food products: a study of Danish consumers' cognitions regarding different applications of vegetable oil. In: 21st Annual IAREP Conference, Social and Economic Representations, Paris

Belletti G, Marescotti A (1998) The reorganization of trade channels of a typical product : the Tuscan extra-virgin olive-oil. In: Arfini F, Mora C (eds) Typical and traditional products: rural effect and Agro-industrial problems, Proceedings of the 52nd Seminar of the EAAE - European Association of Agricultural Economists, June 19-21 1997. Università di Parma, Istituto di Economia Agraria e Forestale, Parma, Italy, pp 271-286

Bevilacqua M, Ciarapica FE, Marchetti B (2012) Development and test of a new fuzzy-QFD approach for characterizing customers rating of extra virgin olive oil. Food Qual Preference 24(1):75-84

Bower JA, Saadat MA, Whitten C (2003) Effect of liking, information and consumer characteristics on purchase intention and willingness to pay more for a fat spread with a proven health benefit. Food Qual Preference 14(1):65-74

Bracco C, Caniglia E, D'Amico M, Di Vita G, Pappalardo G (2009) Analisi del consumo e percezione della qualità dell'olio extravergine d'oliva biologico in Italia. In: Agricoltura Biologica: sistemi produttivi e modelli di commercializzazione e consumo Palermo: Università degli Studi di Palermo, Dipartimento di Economia dei Sistemi Agro Forestali

Brander LM, Koetse MJ (2011) The value of urban open space: Meta-analyses of contingent valuation and hedonic pricing results. J Environ Manage 92(10):2763-2773

Caporale G, Policastro S, Monteleone E (2004) Bitterness enhancement induced by cut grass odorant (cis-3-hexen-1-ol) in a model olive oil. Food Qual Preference 15(3):219-227

Caporale G, Policastro S, Carlucci A, Monteleone E (2006) Consumer expectations for sensory properties in virgin olive oils. Food Qual Preference 17(1):116-125

Carlucci D, De Gennaro B, Roselli L, Seccia A (2014) E-commerce retail of extra virgin olive oil: an hedonic analysis of Italian SMEs supply. Br Food J 116(10):1600-1617

Chan-Halbrendt C, Zhllimab E, Sisiorc G, Imamid D, Leonettie L (2010) Consumer preferences for olive oil in Tirana Albania. Int Food Agribusiness Manage Rev 13:3

Cicia G, Perla C (2000) La percezione della qualità nei consumatori di prodotti biologici: uno studio sull'olio extra-vergine di oliva tramite conjoint analysis. Qualità e valorizzazione nel mercato dei prodotti agroalimentari tipici, Edizioni Scientifiche Italiane, Napoli, pp 237-252

Cicia G, Del Giudice T, Scarpa R (2002) Consumers' perception of quality in organic food: a random utility model under preference heterogeneity and choice correlation from rank-orderings. Br Food J 104(3/4/5):200-213

Cicia G, Del Giudice T, Scarpa R (2005) Welfare Loss due to lack of traceability in extra-virgin olive oil: a case study. Cahiers Options Méditerranéennes 64:19-32

Cicia G, Del Giudice T, Ramunno I (2009) Environmental and health components in consumer perception of organic products: Estimation of willingness to pay. J Food Prod Mark 15(3):324-336

Cicia G, Cembalo L, Del Giudice T, Verneau F (2012) II sistema agroalimentare ed il consumatore postmoderno: nuove sfide per la ricerca e per il mercato. Economia agro-alimentare 1:117-142

Commission of the European Communities (2006a) Council Regulation (EC) No 509/2006 of 20 March 2006 on agricultural products and foodstuffs as traditional specialties guaranteed. Off J Eur Union L93:1-11

Commission of the European Communities (2006b) Council Regulation (EC) No 510/2006 of 20 March 2006 on the protection of geographical indications and designations of origin for agricultural products and foodstuffs. Off J Eur Union L93:12-25

Commission of the European Communities (2009) Council Regulation (EC) No 182/2009 of 6 March 2009 amending Regulation (EC) No 1019/2002 on marketing standard for olive oil. Off J Eur Union L63:6-8

De Graaff J, Eppink L (1999) Olive oil production and soil conservation in southern Spain, in relation to EU subsidy policies. Land Use Policy 16(4):259-267

Dekhili S, d'Hauteville F (2009) Effect of the region of origin on the perceived quality of olive oil: an experimental approach using a control group. Food Qual Preference 20(7):525-532

Dekhili S, Sirieix L, Cohen E (2011) How consumers choose olive oil: the importance of origin cues. Food Qual Preference 22(8):757-762

Del Giudice T, D'Elia A (2001) Valorizzazione dell'olio extravergine d'oliva meridionale: una proposta metodologica per l'analisi delle preferenze. Rivista di Economia Agraria 56(4):11-42

Del Giudice T, Panico T, Caracciolo F, Cicia G (2012) Le preferenze dei consumatori italiani nei confronti dell'attributo biologico nell'olio extra-vergine di oliva alla luce della nuova normativa sull'etichettatura. In: V Workshop Nazionale GRAB-IT 2012, Ancona, 10-11 May 2012

Delgado C, Guinard J-X (2011) How do consumer hedonic ratings for extra virgin olive oil relate to quality ratings by experts and descriptive analysis ratings? Food Qual Preference 22(2):213-225

Delgado C, Guinard JX (2012) Internal and external quality mapping as a new approach to the evaluation of sensory quality-a case study with olive oil. J Sens Stud 27(5):332-343 
Delgado C, Gómez-Rico A, Guinard J-X (2013) Evaluating bottles and labels versus tasting the oils blind: effects of packaging and labeling on consumer preferences, purchase intentions and expectations for extra virgin olive oil. Food Res Int 54(2):2112-2121

Deselnicu OC, Costanigro M, Souza-Monteiro DM, McFadden DT (2013) A meta-analysis of geographical indication food valuation studies: what drives the premium for origin-based labels? J Agric Resour Econ 38(2):204-219

Di Vita G, D'Amico M, La Via G, Caniglia E (2013) Quality perception of PDO extra-virgin olive oil: which attributes most influence Italian consumer. Agric Econ Rev 14(2):46-58

Duval S, Tweedie R (2000) Trim and fill: a simple funnel-plot-based method of testing and adjusting for publication bias in meta-analysis. Biometrics 56(2):455-463

Favati F, Condelli N, Galgano F, Caruso MC (2013) Extra virgin olive oil bitterness evaluation by sensory and chemical analyses. Food Chem 139(1):949-954

Finardi C (2010) Preferenze dei consumatori per attributi di qualità nell'olio extravergine di oliva. Un choice experiment. (Doctoral Dissertation), Retrieved from http://dspace-unipr.cineca.it/

Finardi C, Giacomini C, Menozzi D, Mora C (2009) Consumer preferences for country-of-origin and health claim labelling of extra-virgin olive-oil. In: 113rd EAAE Seminar on: "A resilient European food industry and food chain in a chal-lenging world", 3-6 September, Chania (Greece)

Finco A, Padella M, Sargentoni T (2010) Disponibilità a pagare per la qualità di un olio extravergine locale. Economia Agro-alimentare 12(1):77-98

Finotti E, Bersani AM, Bersani E (2007) Total quality indexes for extra-virgin olive oils. J Food Qual 30(6):911-931

Fotopoulos C, Krystallis A (2002) Purchasing motives and profile of the Greek organic consumer: a countrywide survey. Br Food J 104(9):730-765

Fregapane G, Gómez-Rico A, Inarejos AM, Salvador MD (2013) Relevance of minor components stability in commercial olive oil quality during the market period. Eur J Lipid Sci Technol 115(5):541-548

Fucito R, Vizzarri G (2004) Strategie d'impresa e qualità nel comparto degli oli extra-vergini di oliva molisani. In: Centro studi di estimo e di economia territoriale-ce set, 44th edn., pp 49-81

Gambaro A, Ana CE, Victor P (2013) Influence of subjective knowledge, objective knowledge and health consciousness on olive oil consumption ${ }^{\circ \mathrm{rm}}$ a case study. Food Nutr Sci Vol.04No.04:9. doi:10.4236/fns.2013.44057

Gázquez-Abad JC, Sánchez-Pérez M (2009) Factors influencing olive oil brand choice in Spain: an empirical analysis using scanner data. Agribusiness 25(1):36-55

Glass GV (1976) Primary, secondary, and meta-analysis of research. In: Educational researcher., pp 3-8

Harville DA (1977) Maximum likelihood approaches to variance component estimation and to related problems. J Am Stat Assoc 72(358):320-338

Higgins JPT, Green S (2008) Cochrane Handbook for Systematic Reviews of Interventions Version 5.1.0 [updated March 2011]. The Cochrane Collaboration. Available from www.cochrane-handbook.org

International Olive Oil Council (2012) Table 4: Consumption (1000 tonnes)., http://www.internationaloliveoil.org/ documents/viewfile/4190-consommation1/3. Accessed 11 October 2014

Jiménez-Guerrero JF, Gázquez-Abad JC, Mondéjar-Jiménez JA and Huertas-García R (2012). Consumer Preferences for Olive-Oil Attributes: A Review of the Empirical Literature Using a Conjoint Approach, Olive Oil - Constituents, Quality, Health Properties and Bioconversions, Dr. Dimitrios Boskou (Ed.), ISBN: 978-953-307-921-9, InTech. Available from: http:// www.intechopen.com/books/olive-oil-constituents-quality-health-propertiesand-bioconversions/consumer-preferencesfor-olive-oil-attributes-a-review-of-the-empiricalliterature-using-a-conjoint.

Karipidis P, Tsakiridou E, Tabakis N (2005) The Greek olive oil market structure. Agric Econ Rev 6(1):64

Krystallis A, Ness M (2005) Consumer preferences for quality foods from a South European perspective: a conjoint analysis implementation on Greek olive oil. Int Food Agribusiness Manage Rev 8(2):62-91

Lazaridis P (2004) Olive oil consumption in Greece: a microeconometric analysis. J Fam Econ Issues 25(3):411-430

Leonetti L, Imami D, Stefanllari A, Zhllima E (2009) The olive and olive oil value chain In Albania. Development Solutions Associates., Available via EastAgri. http://www.eastagri.org/files/Oil-Albania.pdf. Accessed 2 October 2014

Lipsey MW, Wilson DB (2001) Applied social research methods series. In: Practical meta-analysis, 49th edn. Sage Publications, London

Mane-Kapaj A, Kapajb I, Chan-Halbrendtc C, Totojanid O (2010) Assessing the comparative advantage of Albanian olive oil production. Int Food Agribusiness Manage Rev 13:1

Marchini A, Diotallevi F, Fioriti L, Pampanini R (2010) A quantitative analysis of olive oil market in the North-West Italy. Enometrics XVII, Palermo

Martínez MG, Aragonés Z, Poole N (2002) A repositioning strategy for olive oil in the UK market. Agribusiness 18 (2):163-180

McEwan JA (1994) Consumer attitudes and olive oil acceptance: the potential consumer. Grasas y aceites 45(1-2):9-15

Menapace L, Colson G, Grebitus C, Facendola M (2008) Consumer preferences for extra virgin olive oil with country-of-origin and geographical indication labels in Canada. In: American Agricultural economics Association Annual Meeting

Menapace L, Colson G, Grebitus C, Facendola M (2011) Consumers' preferences for geographical origin labels: evidence from the Canadian olive oil market. In: European Review of Agricultural Economics:jbq051

Mili S (2006) Market dynamics and policy reforms in the EU olive oil industry: an exploratory assessment. In: Proceedings of the 98th EAAE Seminar "Marketing Dynamics Within the Global Trading System: New perspectives," Chania, Greece

Mili S, Zúñiga MR (2001) Exploring future developments in international olive oil trade and marketing: a Spanish perspective. Agribusiness 17(3):397-415

Moher D, Liberati A, Tetzlaff J, Altman DG (2009) Preferred reporting items for systematic reviews and meta-analyses: the PRISMA statement. Ann Intern Med 151(4):264-269

Monteleone E, Carlucci A, Caporale G, Wakeling I (1997) Analisi della preferenza dei consumatori per I'olio extra vergine di oliva. Rivista Italiana delle Sostanze Grasse 74(9):415-421

Morales MT, Rios JJ, Aparicio R (1997) Changes in the volatile composition of virgin olive oil during oxidation: flavors and off-flavors. J Agric Food Chem 45(7):2666-2673

Mtimet N, Kashiwagi AK, Zaibet L, Masakazu N (2008) Exploring Japanese olive oil consumer behavior. In: 12th EAAE Congress 'People, Food and Environments: Global Trends and European Strategies', Gent (Belgium)., pp 26-29 
Mtimet N, Ujiie K, Kashiwagi K, Zaibet L, Nagaki M (2011) The effects of Information and Country of Origin on Japanese Olive Oil Consumer Selection. In: 2011 International Congress, August 30-September 2, 2011. European Association of Agricultural Economists, Zurich, Switzerland

Mtimet N, Zaibet L, Zairi C, Hzami H (2013) Marketing olive oil products in the Tunisian local market: the importance of quality attributes and consumers' behavior. J Int Food Agribusiness Mark 25(2):134-145

Nakano K, Kubo H, Matsumura S, Saito T, Fushiki T (2013) Effects of aroma components from oxidized olive Oil on preference. Biosci Biotechnol Biochem 77(6):1166-1170

Nelson JP, Kennedy PE (2009) The use (and abuse) of meta-analysis in environmental and natural resource economics: an assessment. Environ Resour Econ 42(3):345-377

Nielsen NA, Bech-Larsen T, Grunert KG (1998) Consumer purchase motives and product perceptions: a laddering study on vegetable oil in three countries. Food Qual Preference 9(6):455-466

Owen RW, Giacosa A, Hull WE, Haubner R, Würtele G, Spiegelhalder B, Bartsch H (2000) Olive-oil consumption and health: the possible role of antioxidants. Lancet Oncol 1(2):107-112

Pagliarini E, Bertuccioli M, Abba S (1994) Consumer attitudes and olive oil acceptance: the traditional consumer. Grasas y aceites $45(1-2): 16-19$

Piccolo D, Capecchi S, lannario M, Corduas M (2013) Modelling consumer preferences for extra virgin olive oil: the italian case. In: Politica Agricola Internazionale/International Agricultural Policy., p 25

Pupo D'Andrea MR (2007) II mercato mondiale dell'olio d'oliva: attori, dinamiche, prospettive e bisogni di ricerca. In: AgriRegioniEuropa 10

Recchia A, Monteleone E, Tuorila H (2012) Responses to extra virgin olive oils in consumers with varying commitment to oils. Food Qual Preference 24(1):153-161

Ribeiro JC, Santos JF (2005) Portuguese olive oil and the price of regional products: does designation of origin really matter? Tékhne Polytechnical Stud Rev 2(3):61-76

Rothstein HR, Sutton AJ, Borenstein M (2005) Publication Bias in Meta-Analysis. In: Rothstein HR, Sutton AJ, Borenstein M (eds) Publication Bias in Meta-Analysis: Prevention, Assessment and Adjustments. John Wiley \& Sons, Ltd, Chichester, UK

Sandalidou E, Baourakis G, Siskos Y (2002) Customers' perspectives on the quality of organic olive oil in Greece: a satisfaction evaluation approach. Br Food J 104(3/4/5):391-406

Santosa M, Guinard J-X (2011) Means-end chains analysis of extra virgin olive oil purchase and consumption behavior. Food Qual Preference 22(3):304-316

Santosa M, Abdi H, Guinard J-X (2010) A modified sorting task to investigate consumer perceptions of extra virgin olive oils. Food Qual Preference 21(7):881-892

Scarpa R, Del Giudice T (2004) Market segmentation via mixed logit: extra-virgin olive oil in urban Italy. J Agric Food Ind Organ 2:1

Scarpa R, Philippidis G, Spalatro F (2005) Product-country images and preference heterogeneity for Mediterranean food products: a discrete choice framework. Agribusiness 21(3):329-349

Sillani S, Esposito A, Del Giudice T, Caracciolo F (2014) Le preferenze dei consumatori della provincia di Trieste per l'olio extra vergine di oliva d'alta gamma. Economia Agro-alimentare 1:139-155

Simpson RJS, Pearson K (1904) Report on certain enteric fever inoculation statistics. Br Med J 2(2288):1243-1246

Soler F, Gil JM, Sanchez M (2002) Consumers' acceptability of organic food in Spain: results from an experimental auction market. Br Food J 104(8):670-687

Thompson SG, Sharp SJ (1999) Explaining heterogeneity in meta-analysis: a comparison of methods. Stat Med 18 (20):2693-2708

Tsakiridou E, Mattas K, Tzimitra-Kalogianni I (2006) The influence of consumer characteristics and attitudes on the demand for organic olive oil. J Int Food Agribusiness Mark 18(3-4):23-31

Van der Lans IA, Van Ittersum K, De Cicco A, Loseby M (2001) The role of the region of origin and EU certificates of origin in consumer evaluation of food products. Eur Rev Agric Econ 28(4):451-477

Vlontzos G, Duquenne MN (2014) Assess the impact of subjective norms of consumers' behaviour in the Greek olive oil market. J Retailing Consum Serv 21(2):148-157

Ward RW, Briz J, de Felipe I (2003) Competing supplies of olive oil in the German market: an application of multinomial logit models. Agribusiness 19(3):393-406

Yangui A, Costa Font M, Gil JM (2013) The effect of food related personality traits and lifestyle orientation on consumer's behavior related to extra virgin olive oil: estimation of an extended hybrid choice model. In: 4th International Conference of the African Association of Agricultural Economists, September 22-25, 2013, Hammamet, Tunisia

Yangui A, Akaichi F, Costa-Font M, Gil JM (2014a) Are ranking preferences information methods comparable with the choice experiment information in predicting actual behavior? In: 2014 International Congress, August 26-29, 2014. European Association of Agricultural Economists, Ljubljana, Slovenia

Yangui A, Costa-Font M, Gil JM (2014b) Revealing additional preference heterogeneity with an extended random parameter logit model: the case of extra virgin olive oil. Spanish J Agric Res 12(3):553-567

Zanoli R, Gambelli D, Naspetti S (2002) II posizionamento dei prodotti tipici e biologici di origine italiana: un'analisi su 5 Paesi. Rivista di Economia Agraria 58(4):477-509 